\title{
VILLA STEIN-DE-MONZIE BY LE CORBUSIER (1926-1928): CONSERVATION STRATEGIES BETWEEN RESEARCH AND EDUCATION
}

\author{
C. Balletti, S. Di Resta, P. Faccio, F. Guerra, M. Pandolfo \\ IUAV University of Venice, Dept. of Architecture Construction Conservation \\ (balletti, sara.diresta, paolo.faccio, guerra2, marta.pandolfo)@iuav.it
}

\section{Commission II, WG II/8}

KEY WORDS: Le Corbusier, modern heritage, conservation, laser scanning, photogrammetry

\begin{abstract}
:
The paper focuses on the educational experience produced during the International Workshop, organized by the IUAV University of Venice and dedicated to both the understanding and conservation of the maison Stein-de-Monzie "Les Terrasses", an emblematic work of Le Corbusier's early career period.

The villa, located in Garches (Vaucresson), was designed and built between 1926 and 1928, the exact same years when Le Corbusier was elaborating the "Five Points of Architecture" (1927): the building is the first complete application of these principles, while it represents an evolution of the maison Dom-Ino's structural scheme.

Nowadays, both the interior spaces and the external surfaces of the maison Stein-de-Monzie show profound changes caused by problematic events leading to the present-day appearance of the building, in many cases misrepresenting the original design goals. The building's integrated instrumental survey (laser scanning, photogrammetry, topography) allowed to document and understand the history of the villa beyond the mere and well known project phase, contributing to the definition of the actual construction characteristics and to ascertain both the material consistency and the state of conservation. The knowledge acquisition process supported by survey data - constitutes a prerequisite to outline the design of new solutions, which could effectively express the cultural choices connected to the conservation of the Twentieth-Century built heritage.
\end{abstract}

Villa Stein-de-Monzie, also known as Les Terrasses, together with Villa Savoye, likely represents the most paradigmatic work in Le Corbusier's career. Villa Stein actually represents the maturity and the accomplishment of the formal, architectural and conceptual elements experimented by Le Corbusier during the ten years preceding the construction.

Art collector Michael Stein and Madame de Monzie, contracted a young Le Corbusier with the idea of a building where the architect could combine comfort, luxury and formal research. With this premise, the architect designed the building with a clear architectural scheme which could define a housing space totally free from its structural framework.

Although the most renown customers were the Stein, the house was built on the Chemin plain, an estate owned by Gabrielle de Monzie, to whom most of the official documentation was addressed (Benton T., 2008). When the building was commissioned, Le Corbusier was still little known; the decision in favor of the architect was jointly taken by Michael Stein and Gabrielle de Monzie, who contributed to a great portion of the building's costs.

From the dates reported on the archival sources we could suggest that Le Corbusier started to draft the project during spring of 1926 and produced the executive papers during the summer of the following year.

Precisely in 1926, Le Corbusier elaborated his famous Five Points of Architecture, publishing the volume in two versions; one edited by Alfred Roth for the Werkbund's exhibition in Stuttgart, within his essay Zwei Wohnhäuser von Le Corbusier und Pierre Jeanneret, and the second one on the magazine L'Architecture Vivante.

The villa in Garches actually represents the first emblematic application of these principles. Differently from the villa La Roche-Jeanneret, which was realized just three years before and was still employing load bearing masonry, villa Stein, according to the First of the Five Points, was realized with reinforced concrete pillars with a section of $20 \mathrm{~cm}$, with a maximum pace of $5 \mathrm{~m}$. The pillars, rearward from the interior of the façades, «crash with the solution of the joists of the reinforced concrete slabs, which, not being homogeneous in the two directions, does not completely corresponds to Le Corbusier's poetical ambitions» (Fanelli G., Gargiani R., 1998; authors' translation). Therefore, the load bearing structure is independent from the other components of the constructions in order to allow a free articulation of the layout.

As stated in the Second Point, on the Southern side of the roofing, a terrace would have been realized protected by walls on the two far ends. Accessible by means of a winding staircase, the panoramic viewpoint allowed to enjoy a view of Paris in the distance. The metal staircase with its balustrade recalls the deck of a ship, reflecting Le Corbusier's appreciation of naval architecture. The Third Point defines the choice to design a free interior plan: clear of load bearing walls, the internal space including the floor and the roof would have allowed any internal partition. The architect chooses to modulate the pillars distribution pace following an A-B-A-B-A pace, allowing a clear separation between the main settings and the service rooms. The distributional scheme proceeds on the basis of a defined program: at the ground floor, the main entrance and the large living room, the entrance area and the secondary restrooms, the garage and the technical room. The second floor (Fig. 1) should have hosted the living room with the library, the dining room and the kitchen. On the third floor were located two bedrooms with private bathrooms, while on the penthouse were four bedrooms, two of them supplied with a bathroom. Almost all the partitions follow the orthogonal grid of the pillars which are often incorporated into the dividing walls. The curved walls, common to all floors, recall the pure and plastic shapes represented in Le Corbusier's paintings of the same period. 
Finally, in accordance to the Fourth and Fifth Points, the façades of the villa would have visually and physically expressed the Le Corbusier's idea of a free façade characterized by long strips of ribbon windows.

Therefore, the villa shows construction aspects which are oriented to allow the creation of a machine d'habiter able to free-stand the structural framework. The building was built by a team of 18 entrepreneurs (Ward J., 1984) acting as executive mediators between the ideas of the architect and the best opportunities to fully realize the building. Fundamental in this process was the Parisian engineer George Summer, who was specialized in béton armé constructions.

Le Corbusier paid great attention to the slab's characteristics: «The general skeleton of the building will be made by a pan de béton armé - pillars and slabs. The slabs will have no ribs in sight» (Le Corbusier, Jeanneret P.; authors' translation).

At the core of the Swiss architect's thoughts were not the construction techniques (although fundamental instrument for achieving the planning goals), instead he believed essential to obtain «straight slabs in their lower face allowing to build free partition walls without the requirement to overlap one over the other» (Le Corbusier, 1929).

Summer was assigned the excavation of the parcel on the 15th April 1927, while the same day he sent Le Corbusier one of his eleven structural plans (Avenue Junot, Propriété de Madame de Monzie, slabs and foundation plans, drawings, FLC 10547-548549-560-563-575 576-578-561-515-564).

\section{Beyond the original project}

Differently from other works, perfect expression of the International Style, Les Terrasses is far from appearing a simple reinforced concrete monolith. Clearly visible in the first buildings of Le Corbusier, the purist idea of the Swiss architect is actually confirmed in Vaucresson through a clear will to conceal the construction characteristics of the building below a smooth skin of painted plasters: in the architect's idea, a skeleton of reinforced concrete (Fig. 2) defined by a frame of pillars and straight slabs was aimed to enable a free articulation of the plan.

The outcome was reached thanks to a new patent by Summer (Summer G., a). He invented a process that enabled to pour the slabs directly on site with a concavity to the top, which were probably finished with bricks. The historical images from the building site show the composition of this slab realized with concrete beams poured on site (Fig. 3). Further archival documentation (Building site photography, FLC L1-10-6) testifies how the walls of the villa had been realized with hollow bricks and mâchefer concrete blocks of various dimensions, successively encased by gypsum plaster (for internal surfaces) and by ciment pierre - specifically ciment simili-pierre Poliet \& Chausson - for the façades (Le Corbusier, Jeanneret P., Propriété de Madame de Monzie. Description Générale, typescript, FLC H1-4-24/29). No insulation was expected to address the problem of infiltration of rainwater on the terraces, nor to contain the issue of heat loss from the walls.

Although at the end of the 1920s Le Corbusier was committed to various other projects, during the construction of Villa Stein he visited the site several times. In some occasions, the visits brought to relevant changes on the original project's idea. In fact, the building plans register changes, afterthoughts and sometimes revisions, some of them deriving from the relation with the Summer construction company.

The typescript «Mémoire n.1» (Summer G., b), compiled by the company in March 1928, reports the removal of the circular opening on the external terrace in correspondence to Madame de Monzie's bedroom. This was probably due to the excessive space taken by the opening.

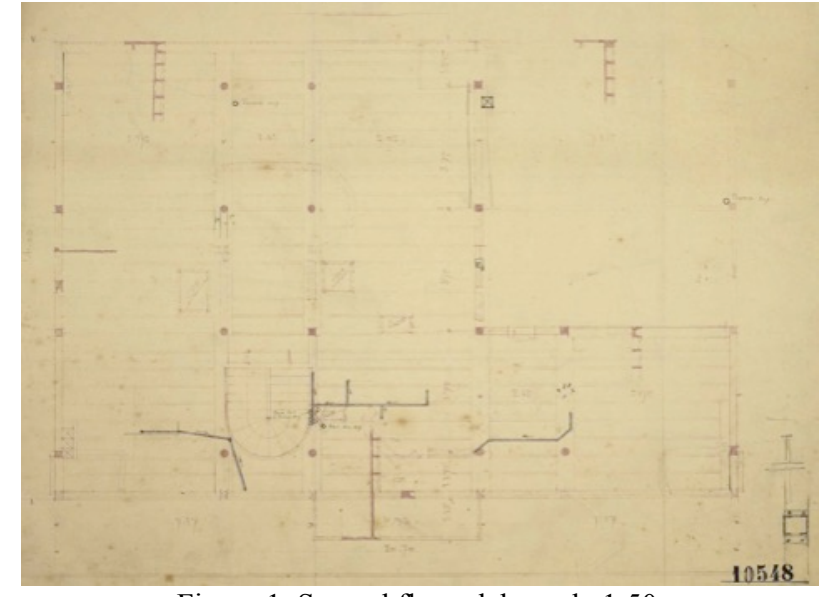

Figure 1. Second floor slab, scale 1:50, March 29, 1927 [FLC 10548]

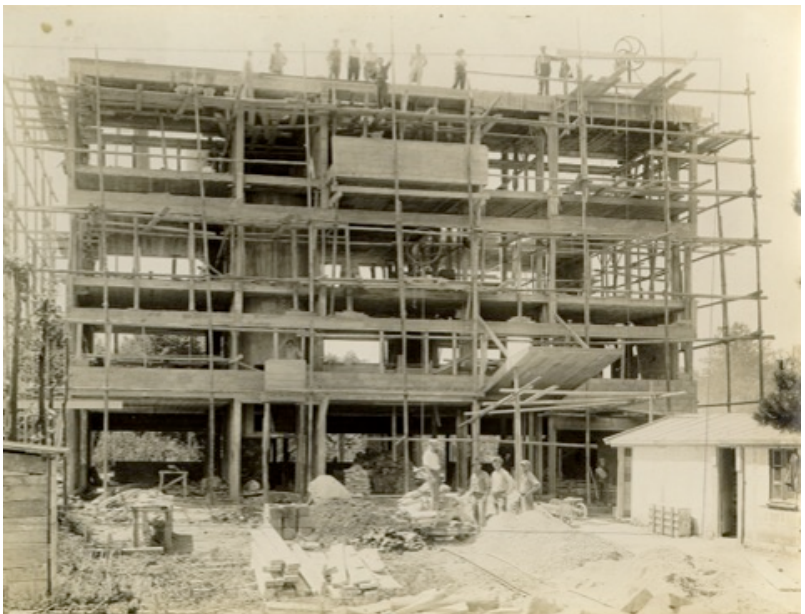

Figure 2. Northern façade, building site [FLC L1-10-8]

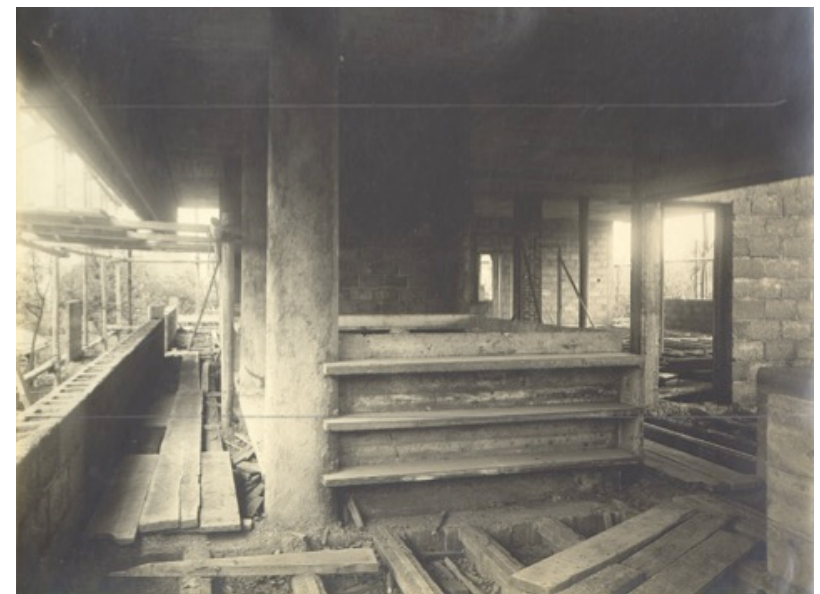

Figure 3. Internal view of the building site, first floor [FLC L1-10-3]

In terms of the project definition, the higher contribution of the Summer company regarded the choice to increase the section of the pilotis north to the ground plan and, on the second floor, the change of their section to an airplane wing shape, most likely to improve the strength in coincidence of the large tie-beams for the suspension of the external entrance roof (Rue de Sèvres, Stein de Monzie, details of the entrance roof, drawing 872, FLC 10443). 
It needs to be stressed that the position of the tie-beams of the entrance roof (Fig. 4) does not allows a continuity of the construction axes between the two structural elements, leaving to assume a discrepancy in the relationship between the structure's geometry and the rhythmic composition of the façade. Another important change was finally represented by the doubling of the facade's little pillars, which does not appear in the executive plan for the first version of the project.

The villa was completed in 1928 and inhabited by the Stein family for seven years. In opposition to the architect's will, the interiors were furnished with their oriental textiles, Italian Renaissance furniture and their art collection.

In 1934, Michael Stein, concerned about the events that would lead to the outbreak of the Second World War, decided to sell the villa.

\section{A significant transformative path}

In 1935, the villa was bought by a Norwegian banker, known as Mr. Steen. The new owner contacted the Swiss architect to realize a new marble covering for the façades (Rue de Sèvres, Stein de Monzie, Northern and Southern façades with marble covering, drawing, FLC 10529-530. The new covering project was never realized), a fireplace (Rue de Sèvres, Stein de Monzie, plan and section of the chimney, drawing, FLC 10457), new steel and glass furniture (designed by Charlotte Perriand) and to resolve a series of construction defects arising only seven years after the inauguration of the building. During WWII the villa was completely abandoned (Ward, 1984). In 1959, the heiress of the Société Immobilier de Saint Cloud, Dorethee Kieling, decided to subdivided the villa in four smaller apartments, one on each floor, thereby breaking the unity of the system and significantly altering the distribution features.

Nowadays, the internal spaces of the villa, as they were defined by the original project, have partially disappeared precisely because of the subdivision of the villa in apartments. If, from the outside, the perception of the building remains unvaried, only partially modified by the traces of time on the plasters and metal elements, the adaptation to the new residential standards has actually produced many transformations.

Altered in the spatial features and in the material consistency of the surfaces (Figg. 5-6), the only unvaried characteristic of Le Corbusier's original project is probably the structural frame built in reinforced concrete, testimony of a complex experimental work and outcome of a solid collaboration between the architect and a knowledgeable executing company. Carried out with the collaboration of professors in architectural conservation, survey, history of architecture and construction techniques, the Workshop was addressed to the students of the Master Degree "Architecture for the New and the Ancient" at IUAV University in Venice.

The first aim of the workshop was to cross-reference information deriving both from the archival research and the activities in situ. This approach allowed to reconstruct the history of the villa as traced so far in this paper. The historical account attempted to offer a wide view, far from being just a project and construction chronicle, instead attempting to recount of the articulated path that brought to the creation of the architecture that we can experience nowadays, highlighting its material consistency and the sometimes-problematic transformations it has undergone.

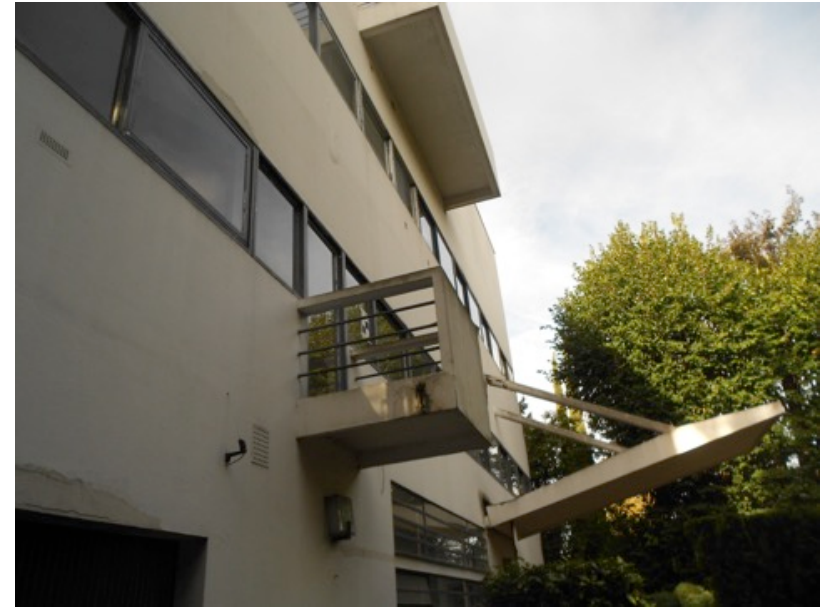

Figure 4. Detail of the Northern façade, current state [Di Resta, 2015]

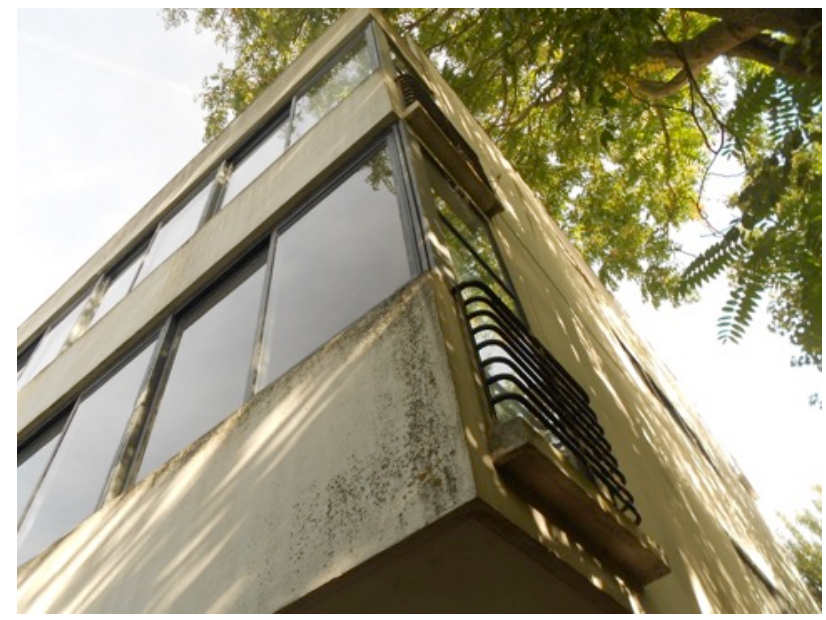

Figure 5. Detail of the South-East corner, current state

[Di Resta, 2015]

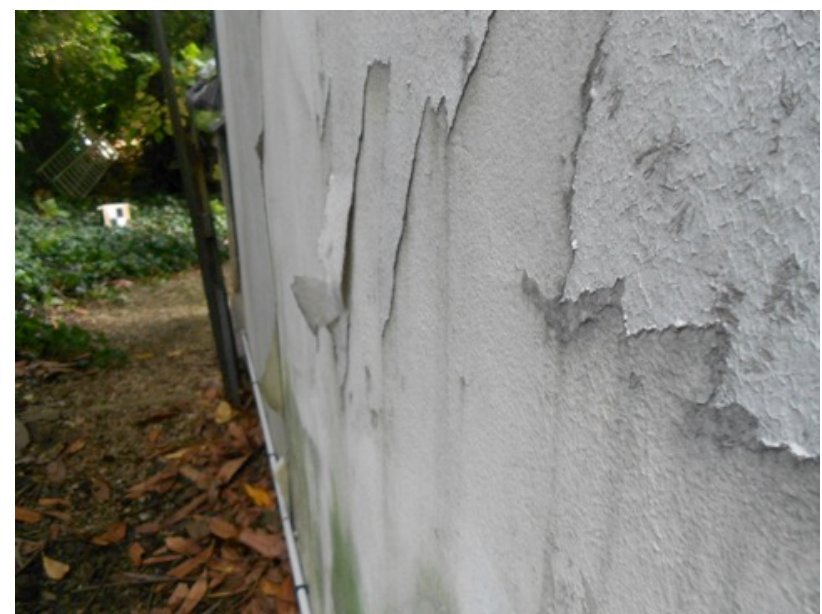

Figure 6. External surfaces decay, Eastern façade, current state

[Di Resta, 2015] 


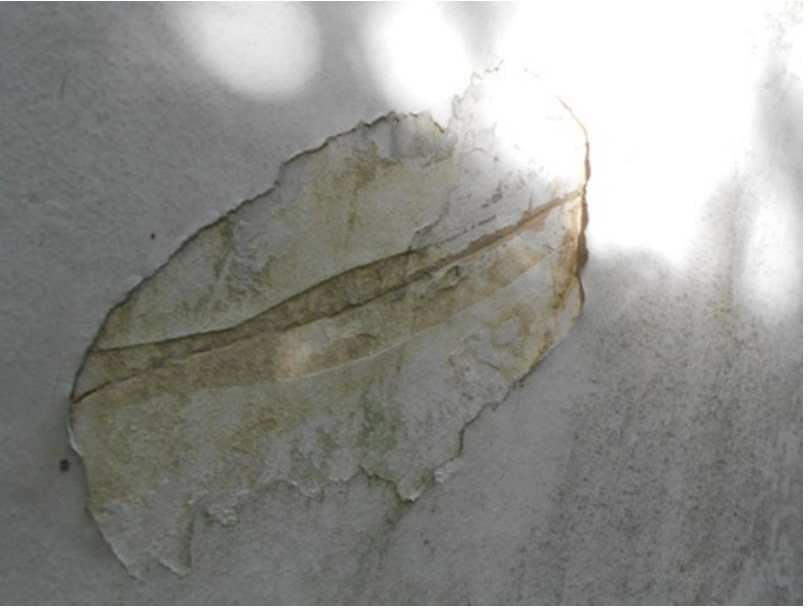

Figure 7. External surfaces decay, Eastern prospect, current state [Di Resta, 2015]

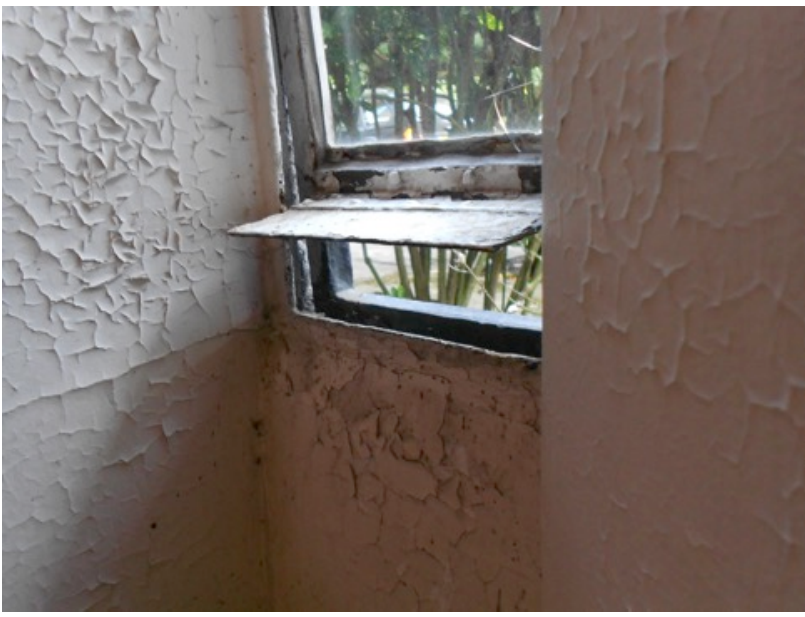

Figure 8. Internal surfaces and frames decay, current state

[Di Resta, 2015]

\section{Surveying maison Stein-de-Monzie}

The integrated survey (laser scanning, photogrammetry, topography) was jointly undertaken by educators and students at Iuav University in Venice, allowing to reconstruct the building's history, to define the current building features and to determinate the physical/material consistency and the state of conservation.

Surveying contemporary architecture implies several importan considerations that lay at the basis of a shared teaching and learning experience.

In planning restoration works for 20th century architecture, the implementation of instrumental survey is not very common, as most of the time this kind of intervention is not required or, simply because, the original project's documentation (autographic documents, site sketches, photographs, video documentation, direct evidence left by labourers and collaborators) are still accessible and sufficient to inform restoration interventions. This approach is also based on an economic reason, since instrumental survey of complex architectures can be a quite expensive endeavour.

Nonetheless, this approach is also debatable as it is based on a flimsy preconception: namely, a direct and unvaried relationship between design and construction.

Although the categories which characterize the project, such as the geometry, are common to the survey and project design, the two represent different exercise.
In fact, it is clear that they could never correspond: the project design represents a drawing that foreshadows time and it is projected into the future. Indeed, the term "project" originates from the Latin pro-iacere which means "to push forward", having a definite meaning prompting intention as well as prefiguring time.

Conversely, the survey design looks back: it studies, represents and defines a present configuration determined by past events. It represents a post quem design.

Project and survey designs have the working outcome in common; nonetheless, among the two designs are the construction work, the site, the employed matter, and the skilled workers; these are all elements introducing new geometries. The temptation to superimpose the two designs could be overwhelming as the time proximity between the two phases allows us to follow through the building events and to reconstruct transformations leading to the visible differences between the two designs' outcomes.

In conclusion, the problem is moderately related to the closeness or remoteness of the construction, or to assessing the differences based on historical events: project and survey simply are two different designs in terms of their origin, nature and scope.

Surveying, as analysis, studies the form of the architecture through the geometries of the building, geometries that play an essential role in the processes of conception, construction and comprehension which have involved the building over its lifetime. But survey isn't only an analysis of geometries: it is instrumental to the other analyses since it provides a metric and topological basis on which to spatially locate the phenomena being studied. Frequently, very different phenomena are correlated by the fact that they have the same position or are reciprocally located according to their own logic.

Therefore, if we lend survey this essentially documentary value, it is worthwhile to think about the possibilities offered by the current techniques for realization of surveys and representations that allow us to document the work of Le Corbusier in accordance with our knowledge and conservation.

The survey becomes a very complex operation both from the methodological and operational point of view. It requires critical interpretation abilities for a correct comprehension of the surveyed object from which the correct strategies can be derived to obtain the best result from the survey operations. As is well known (Balletti c. et al, 2014, Balletti c. et al, 2015, Remondino et al., 2010), there is a variety of techniques available to generate three-dimensional survey information necessary to understand differences between design and reality. These techniques can be characterised mainly by the scale at which they might be used which is related to the size of the object to be measured, or to the complexity of the object (English Heritage, 2011).

Digital photogrammetry and terrestrial laser scanning could be used to provide a greater number of measurements for similar object sizes, and therefore, are suitable to be integrated for more complex objects acquisition.

The Villa, as seen today, was surveyed with a range image laser Focus3D by Faro. The instrument, well known in the field of architectural surveying (Balletti c. et al, 2013), has shown itself to be particularly suited to the acquisition of data both internally and externally. These applications are related not only to documentation but also to the sectors of restoration and industry. The apparatus is extremely rapid and its dimensions and weight are limited. This laser scanner, endowed with a wlan (wifi) which allows one to manage the scanning at a distance removed from the work area, is characterized by a range between 0.6 and $120 \mathrm{~m}$ and an accuracy of $\pm 2 \mathrm{~mm}$ for distances ranging from 10 to 25 meters. 

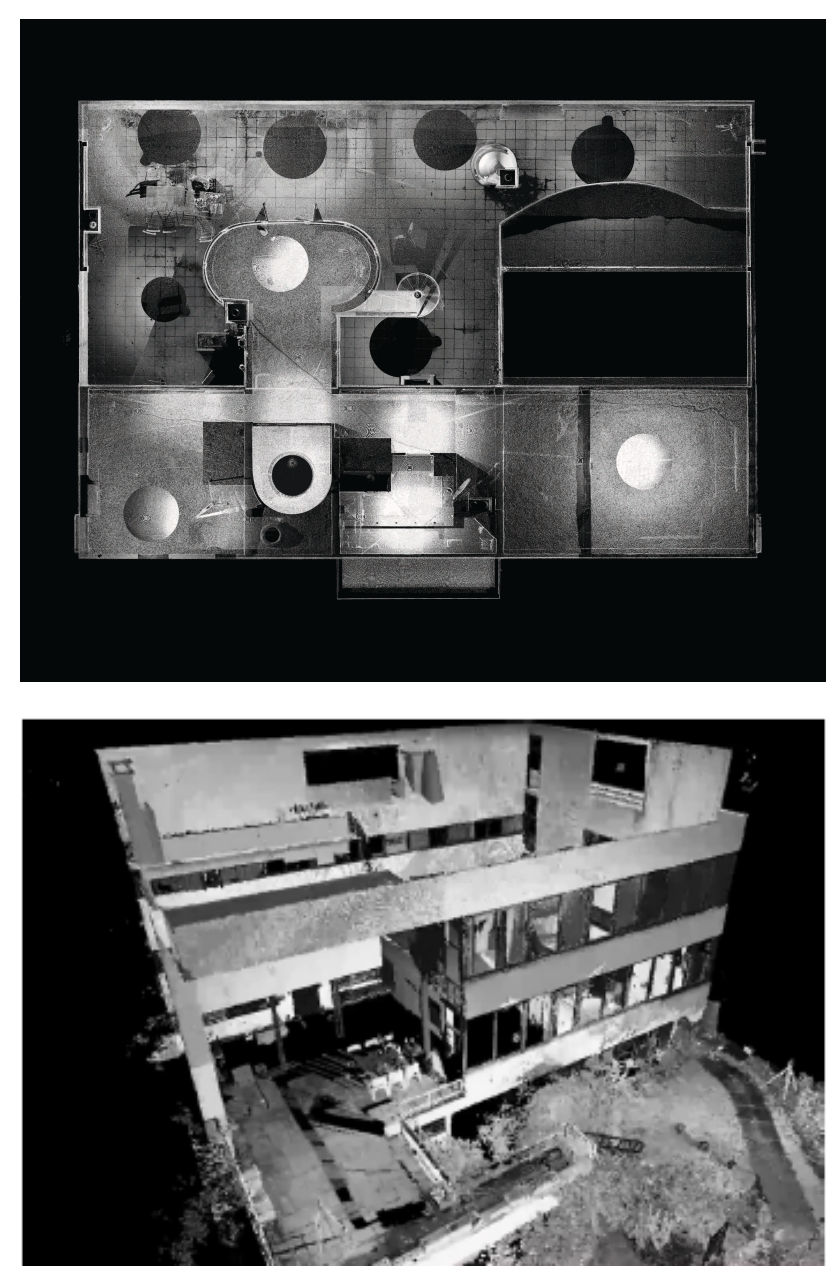

Figure 9-10. The laser scanning point clouds

The instrument provided the precision necessary for the surveying of the Villa. Its ample visual field (a vertical of $305^{\circ}$ and a horizontal of $360^{\circ}$ ) renders it particularly suited to constricted urban areas. The velocity of the scans (up to 976.000 points $/ \mathrm{sec}$ ) and that selected for this project $(244 \mathrm{kpt} / \mathrm{sec})$ allowed for a reduced scanning time (about 7-8 minutes per scan). Each acquired point is characterized by an RGB value thanks to the integrated digital photo camera with a 70 megapixel resolution.

Every scan was placed to identify 3 target at least, trying to avoid all the elements that could create noise, such as people, animals or vegetation.

30 scans were acquired in the ground floor, inside and outside in the garden, 34 scans covered the first floor, 2 were at the second floor, 17 at the third floor and, finally, 14 scans along the stairwell. Totally 97 point clouds and 1.767 .481867 points were acquired.

The acquisition of the scans was accompanied by topographical support for a greater control of the cloud alignments in the same reference coordinates system; a Leica TCR 1103 theodolite was used not only for control point acquisition, but even to realize the local reference system.

To integrate laser scanning data, the external facades and the terrace on the roof was surveyed by unconventional digital photogrammetry.

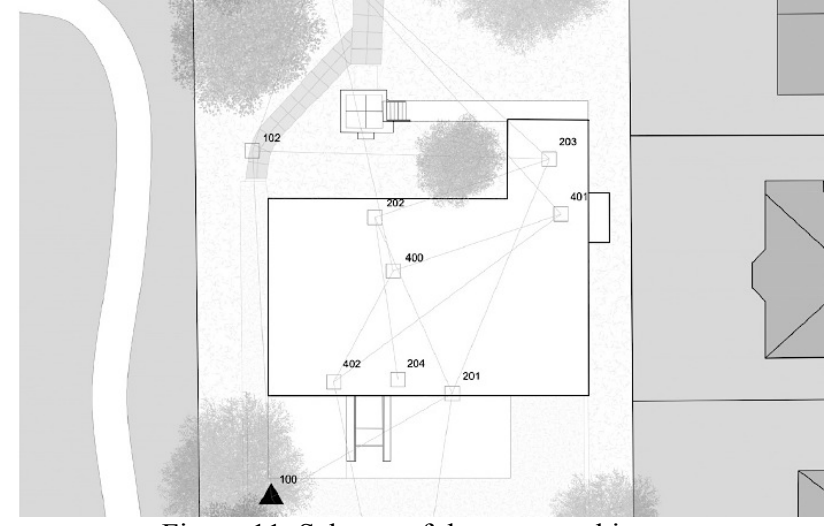

Figure 11. Scheme of the topographic net

The image-based techniques, using algorithms derived from Computer Vision, such as the well known Structure from Motion, (Remondino et al. 2006), are able to automatically perform the whole pipeline reducing time both for images orientation and $3 \mathrm{D}$ reconstruction. Nowadays we can work with software applications (such as Photomodeler, used for this case), which automatically perform camera self-calibration and offer the possibility use several cameras and sensors (as it was for the Villa) to obtain dense point clouds or 3D.

\section{The representation of the Villa}

Considering the state of art of Cultural Heritage's documentation, it is necessary to evaluate which model of representation of the digital data has to be chosen. In a society in which visual communication now has a fundamental role in disseminating information, the 3D model, appropriately adjusted through today's technological possibilities, can provide a message that is easily perceived and extremely incisive in communicating information about Heritage.

The overlapping and the integration of Geomatics with Computer Graphics is clear: alongside the more traditional Monge projections, where vectorial restitutions are integrated with orthophotos and-rectifications, three-dimensional models, also texturized, are more often proposed and they can be visualized through animation or applications of virtual reality. Using the point cloud generated by laser scanning, and Pointools Edit software, plans of the different floors of Villa Stein were obtained, just slicing the data through horizontal planes; moreover the four facades and three sections, projecting the pointcloud on vertical planes. All representations were made at a scale of 1:50.

For a better understanding of the space inside and outside the maison, a digital $3 \mathrm{~d}$ model was done, such as an effective support to document the current status of the Villa and also as a base for any other forms of communication and dissemination, regarding its history, oriented to a wide public.

Based on the comparison between the representations produced by the survey of the state of Villa Stein and some historical drawings, published by Le Corbusier in the Oeuvre Compl.te 1910-1929, it was easy to see a strong discontinuity.

The historical analyses has shown that today's villa is the result of numerous transformations and changes that occur over time, from the beginning of his design process.

Nowadays the original design spaces of Villa disappeared, as the building was divided into five separate apartments that have altered the functionality designed by Le Corbusier.

The only invariant to the initial project is the structural grid, still visible today, such as the only testimony to the work performed by the Architect. 


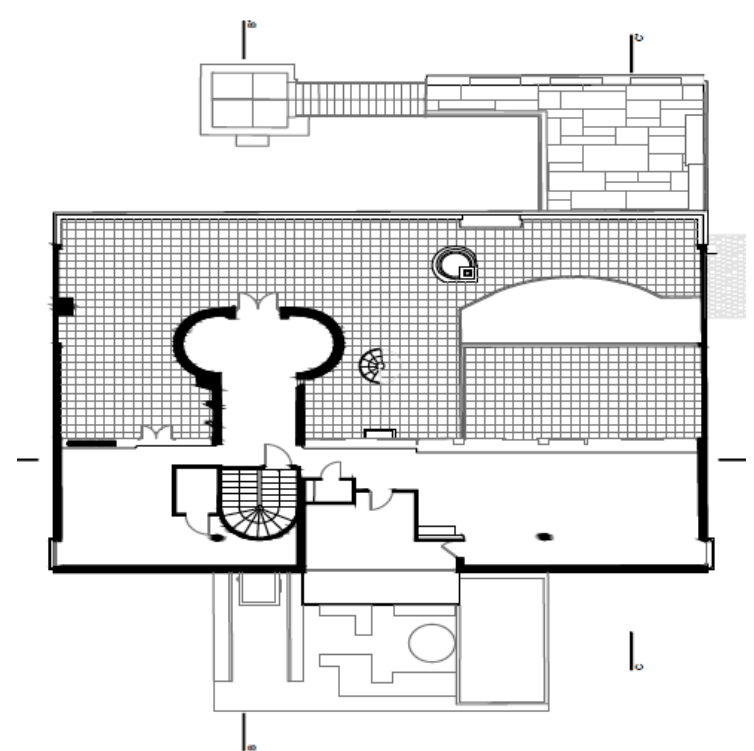

Figure 12. Plan of the third floor

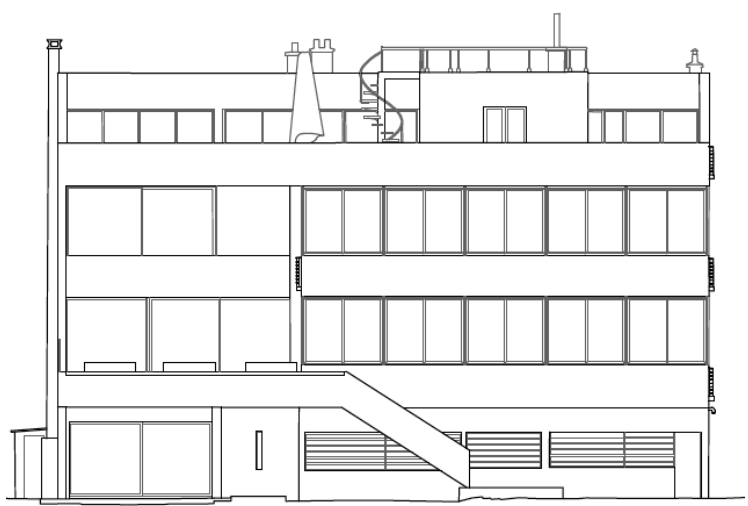

Figure 13. North façade

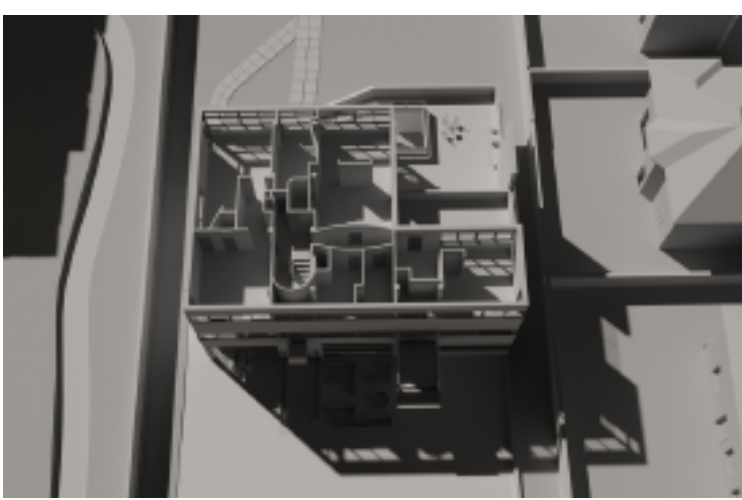

Figure 14. View of the modeled third floor

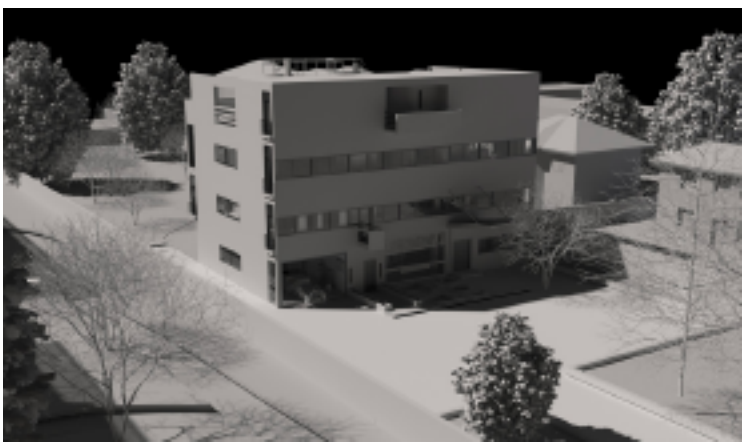

Figure 15. View of the model

\section{Conclusions}

We have already stressed how the internal spatial subdivisions and the external surfaces of the Stein-de-Monzie's villa appear profoundly modified due to historical events that involved the building until today, often overturning the original project's ideas and goals. The understanding of the project and construction procedure and the awareness of the events involving the villa can and should guide the survey and restoration projects planning, in terms of the research question to be addressed and the opportunities for the survey and conservation exercises to answer those questions.

A direct knowledge of the architecture, archival sources and documentation - preserved by the Fondation Le Corbusier, supporter of the workshop - allowed to achieve highly relevant results, both from a research and teaching points of view.

In the first place, it allowed to ascertain the actual geometrical, constructive and conservative characteristics of the building as exemplified by the images presented in this paper.

It also allowed to document a rich stratigraphic matrix, characterizing today's surfaces of a highly transformed architecture.

Ciment pierre plasters appear in areas were successive plasters coverings are falling off (Fig. 7), calling for a thorough stratigraphic study in order to recall their extension and state of conservation, prior to an evaluation over the opportunity to restore and bring them back to light.

Further detailed studies are also required on the internal surfaces (Fig. 8), which have undergone even more trenchant transformation over time. These studies should be addressed to verify the existence of gypsum plasters below the more recent plasters layers.

A direct relation with the building enabled students, in the middle of their training path, to confront with a fundamental research question which characterizes 20th century architecture and its own fate: many symbolic buildings of the century are nowadays altered in their material consistency and affected by obsolescence phenomena caused by, both, the construction techniques and the new instances of living.

Leveraging, among the other type of data, on the data acquired through the instrumental survey, the knowledge acquisition process constitutes a prerequisite to inform the design of new solutions, which could effectively express the cultural choices connected to the conservation of the cultural heritage site.

\section{REFERENCES}

Balletti, C., Guerra, F., 2015. The survey of cultural heritage: a long story. Rendiconti Lincei, 26: 115-125. doi:10.1007/s12210-015-0411-8

Balletti, C., Brussa, N., Gottardi, C., Guerra, F.: The documentation and reintegration of a lost past, ISPRS Ann. Photogramm. Remote Sens. Spatial Inf. Sci., II-5, 49-55, doi:10.5194/isprsannals-II-5-49-2014, 2014

Benton, T., 1990. Villas of Le Corbusier and Pierre Jeanneret 1920-1930, Yale University Press, Yale

Boesiger W., Stonorov O., 1999. Le Corbusier, Oeuvre Complete, Tome I 1910/1929, Birkhauser, Basel, pp. 501-574

Caccia S., 2014. Le Corbusier dopo Le Corbusier. Retoriche e pratiche nel restauro dell'opera architettonica, Franco Angeli, Milan

Curtis W., 1986. Le Corbusier: ideas and forms. Phaidon, Oxford 
English Heritage, 2011. 3D Laser Scanning for Heritage. Advice and guidance to users on laser scanning in archaeology and architecture. Available at www.english-heritage.org.uk

Etlin, R., 1987. A Paradoxal Avant-Garde: Le Corbusier's Villas of the 1920s, in Architectural Review, January, pp. 24-25

Fanelli G., Gargiani R., 1998. Storia dell'architettura contemporanea: spazio, struttura, involucro. GLF editori Laterza, Rome

Fanelli G., Gargiani R., 1990. Perret e Le Corbusier: confronti, Laterza, Bari

Gargiani R., Rossellini A., 2011. Le Corbusier: Béton Brut and Ineffable Space, 1940-1965: Surface Materials and Psychophysiology of Vision. Lausanne: Ecole Polytechnique Fédérale de Lausanne, Routledge, Oxford

Le Corbusier, Jeanneret P., Propriété de Madame d Monzie. Description Générale. Typewritten document, Paris, Fondation Le Corbusier, H1-4-24/29

Le Corbusier, 1946. L'espace indicible, in L'Architecture d'Aujourd'hui, Paris, Nov-Dec, pp. 9-17

Le Corbusier, Réalisations et projets, in Architecture Vivante, VII, 1929, p. 32

Pandolfo, M., 2016. Villa Strein, struttura e architettura Trasformazioni e invarianti, in Faccio, P. (edited by), Le Corbusier. Sette architetture, Altralinea, Florence, pp. 97-194

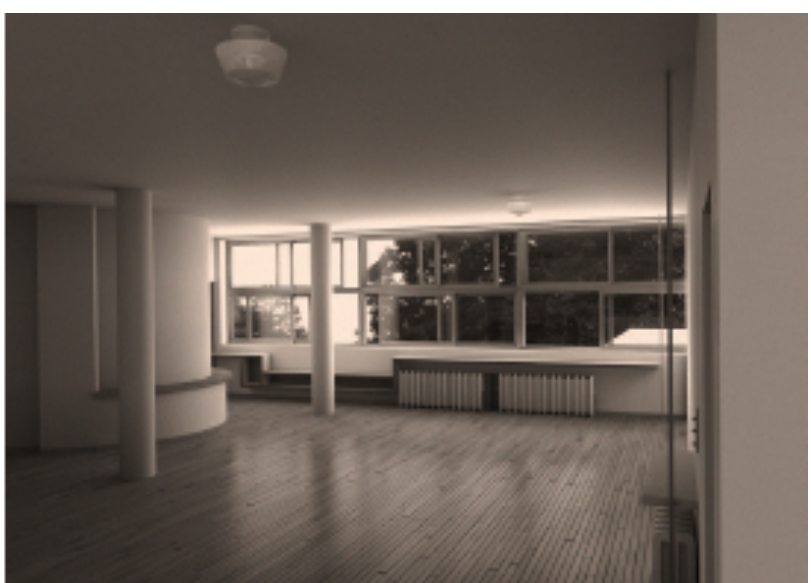

Figure 16. Rendering of one of the room in the original design

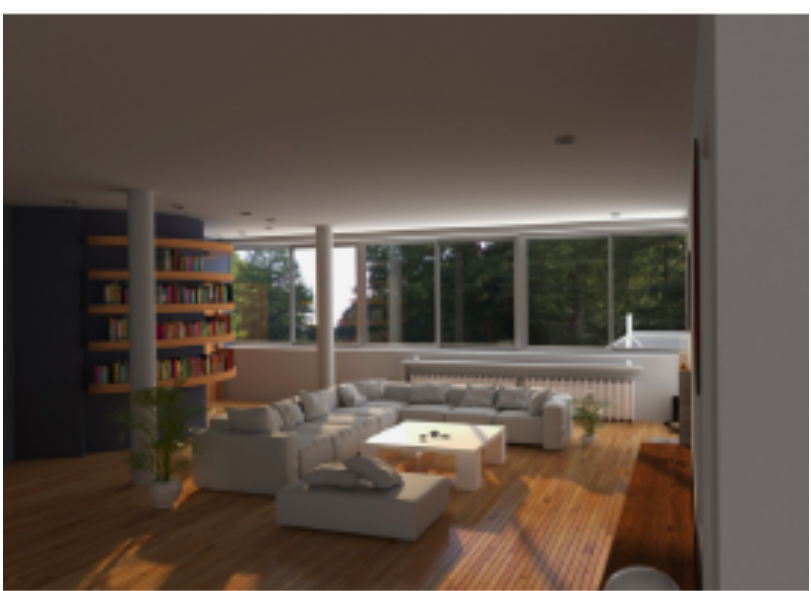

Figure 17. Rendering of the same room today
Reichlin, B., 1985. Mallet-Stevens VS De Stijl, in Bois, Y. A., Reichlin, B. (a cura di), De Stijl et l'architecture en France, Mardaga, Bruxelles, pp. 109-120

Remondino, F., Rizzi, A., 2010. Reality-based 3d documentation of natural and cultural heritage sites techniques, problems and examples, Applied Geomatics, Vol.2 (3), pp. $85-100$

Remondino F, El-Hakim S. (2006) Image-based 3D modelling. A review. Photogramm. Rec. 2006, 21:269-291

Rossellini A., 2013. Le Corbusier e la superficie: dal rivestimento d'intonaco al béton brut, Aracne, Rome

Rowe C., 1981. The Mathematics of the Ideal Villa and Other Essays, The MIT Press Cambridge, London

Soth L., 1983. Le Courbusier's Clients and Their Parisans Clients in the 1920s, in Art History, June, vol. 6, pp. 188-198

Summer G. (a). Brevet d'Invention. Procède et appareil pour la construction des planchers en béton arme, et produit nouveau en résultant. Typescript, Paris, INPI Institut National de la Propreté Industrielle.

Summer G.(b). Propriété de Madame d Monzie. Travaux exécutés sous les ordres des Monsieur Jeanneret Architecte. Mémoire n.1, typescript, Paris, Fondation Le Corbusier, H1-4-

Turner P.V., E Crippa M.A., 2001. La formazione di Le Corbusier: idealismo e movimento moderno. Jaca book, Milano

Von Moos S., 1979. Elements of synthesis, MIT, Cambridge

Ward J., 1984. Les Terrasses and the International Style. New York University: Graduate School of Arts and Science, pp. 7172,167 